\title{
Competencies for young European higher education graduates: labor market mismatches and their payoffs
}

Citation for published version (APA):

Garcia, A. L., \& van der Velden, R. K. W. (2008). Competencies for young European higher education graduates: labor market mismatches and their payoffs. Higher Education, 55(2), 219-239. https://doi.org/10.1007/s10734-006-9050-4

Document status and date:

Published: 01/01/2008

DOI:

10.1007/s10734-006-9050-4

Document Version:

Publisher's PDF, also known as Version of record

\section{Please check the document version of this publication:}

- A submitted manuscript is the version of the article upon submission and before peer-review. There can be important differences between the submitted version and the official published version of record.

People interested in the research are advised to contact the author for the final version of the publication, or visit the DOI to the publisher's website.

- The final author version and the galley proof are versions of the publication after peer review.

- The final published version features the final layout of the paper including the volume, issue and page numbers.

Link to publication

\footnotetext{
General rights rights.

- You may freely distribute the URL identifying the publication in the public portal. please follow below link for the End User Agreement:

www.umlib.nl/taverne-license

Take down policy

If you believe that this document breaches copyright please contact us at:

repository@maastrichtuniversity.nl

providing details and we will investigate your claim.
}

Copyright and moral rights for the publications made accessible in the public portal are retained by the authors and/or other copyright owners and it is a condition of accessing publications that users recognise and abide by the legal requirements associated with these

- Users may download and print one copy of any publication from the public portal for the purpose of private study or research.

- You may not further distribute the material or use it for any profit-making activity or commercial gain

If the publication is distributed under the terms of Article $25 \mathrm{fa}$ of the Dutch Copyright Act, indicated by the "Taverne" license above, 


\title{
Competencies for young European higher education graduates: labor market mismatches and their payoffs
}

\author{
Adela García-Aracil · Rolf Van der Velden
}

Received: 14 April 2006/ Accepted: 20 December 2006/ Published online: 3 March 2007

(C) Springer Science+Business Media B.V. 2007

\begin{abstract}
Labor market rewards based on competencies are analyzed using a sample of young European higher education (HE) graduates. Estimates of monetary rewards are obtained from conventional earnings regressions, while estimates total rewards are based on job satisfaction and derived through ordered probit regressions. Results for income show that jobs with higher participative and methodological competency requirements are better paid. The results also show that higher requirements in terms of competencies increase graduates' job satisfaction.
\end{abstract}

Keywords Assignment theory $\cdot$ Competencies $\cdot$ Income $\cdot$ Job satisfaction · Labor market mismatches

\section{Introduction}

Human capital competencies, understood as those talents, skills and capabilities of $\mathrm{HE}$ graduates that contribute to multi-factor productivity gains, are perceived as a key element for sustainable economic growth and development in the globalize economy (Hartog, 1992; Sianesi \& Van Reenen, 2003). Increasingly, policy makers are focusing on the importance of competencies with a focus on: linkages between productivity (Buchel, 2002); the demand for competencies and globalization (De la Fuente \& Ciccone, 2003); the need to take advantage of new technologies (Mariachristina, Santarelli, \& Vivarelli, 2003); problems of labor market transition among

\footnotetext{
A. García-Aracil ( $ه)$

Institute for Innovation and Knowledge Management, INGENIO (CSIC-UPV),

Spanish Council for Scientific Research,

Technical University of Valencia,

Camino de Vera, 46022, Spain

e-mail: agarcia@ingenio.upv.es

R. Van der Velden

ROA, University of Maastricht, Maastricht, 6200 MD, The Netherlands
} 
young adults (Bradley \& Nguyen, 2004). High levels of education, defined conventionally as more years of education, are not enough; modern complex societies are demanding specific competencies. Individuals can obtain these competencies through experience, training, or more informal means (Hartog, 2001; Rychen \& Salganik, 2003). Formal learning may increase or decrease differences in the abilities and levels of competence of individuals (Ishikawa \& Ryan, 2002; Neumark \& Wascher, 2003; Tyler, Murnane \& Willett, 2003).

The introduction of new technologies changes the nature of work, and affects the value and content of the competencies required (Mariachristina et al., 2003). Some competencies accumulated by workers will become less relevant, while others will become crucial. This is standard thinking about technological change and "skills" obsolescence and is the logic behind vintage human capital (De Grip, Van Loo \& Mayhew, 2002). Evidence of growing wage gaps between more- and less-skilled individuals has drawn attention to the emergence in economies of a skill-intensity bias in labor demand (Acemoglu, 1998; Autor, Katz \& Krueger, 1998; Berman, Bound \& Machin, 1998; Levy \& Murnane, 1992). Therefore, technological change generates a mismatch between the supply of and demand for competencies, and wage inequality results from the inability of the supply side to keep up with demand requirements (Witte \& Kalleberg, 1995; Thurow, 1975).

These changes have raised concerns about the accuracy of the match between HE and employment of graduates in Europe (Hoogveld, Paas, \& Jochems, 2005; Heijke, Meng \& Ris, 2003; Teichler \& Kehm, 1995; Witte \& Kalleberg, 1995). Among these concerns, two have attracted the attention of researchers. The first is the identification of those competencies that are more relevant to graduates' professional success (Busato, Prins, Elshout \& Hamaker, 2000; Robinson, Sparrow, Clegg, \& Birdi, 2005; Heijke, Meng \& Ramaekers, 2002). The second is whether and how these competencies are generated (or may be promoted better) by HE systems in Europe (Belfield, Bullock \& Fielding, 1999; Dolton \& Makepeace, 1990; Kuh, 1999, 2001; Leckey \& McGuigan, 1997; Pike, 1995; Yang, You \& Chen, 2005). Providing a clear answer to these questions is far from straightforward due to the heterogeneity of the productivity-enhancing characteristics of graduates.

Analysis of the matching between job level and level of education based on the notion of an adequate match as a one-to-one relation is vulnerable to the criticism that it involves a very rigid view of optimal allocation (Barro \& Loewenstein, 1985; Hartog \& Oosterbeek, 1988; Jovanovic, 1979, 1984; Topel, 1986). In this sense, job level is a variable that measures the complexity of a job, often expressed as the required ability level of a worker, and sometimes as required education (Hartog, 2001). It suggests the existence, for each level of education, of an optimum job level and the implication that allocation to any other job level is necessarily suboptimal, particularly, with respect to under-utilization. If this match is not optimal, additional learning through training and work experience will be needed to improve or adjust the initial competencies acquired during education. Indeed, the importance of on-the-job training for improving competencies has long been emphasized (Becker, 1964; Mincer, 1974) and there have been many debates about its impact on productivity and wages (Acemoglu \& Pischke, 1998; Brown, 1989; Kunze, 2005; Lynch, 1992; Pischke, 2000; Raaum \& Torp, 2002).

In the absence of data on individual productivities, a major line of research has developed regarding the effect of education-job mismatches on wages, based on so-called assignment models. Two basic models have been used to study the wage 
effects of over- and under-education. The most common approach is to define the number of years of schooling that are "adequate" or "required", for a given job or occupation (denoted as Er); if E denotes total years of schooling completed, then years of over-education are given by $\mathrm{Eo}=\mathrm{E}-\mathrm{Er}$ if $\mathrm{E}>\mathrm{Er}$ and years of undereducation are defined by $\mathrm{Eu}=\mathrm{Er}-\mathrm{E}$ if $\mathrm{E}<\mathrm{Er}$. The rewards from education are then separated into rewards in the case of a "proper matching" and corrections for under- and over-education (Charlot \& Decreuse, 2005; Chevalier, 2003; Groeneveld \& Hartog, 2004; Hartog \& Oosterbeek, 1988; Verdugo \& Verdugo, 1989).

According to those models, individuals working in jobs for which a higher level of education than they actually have, is required (under-education) will often earn more than individuals with the same level of education working in jobs for which their level of education is appropriate, but less than individuals with the level of education that is actually required (Cohn, 1992; Cohn \& Khan, 1995; Duncan \& Hoffman, 1981; Hartog \& Oosterbeek, 1988). Conversely, individuals working in jobs for which a lower level of education than they have is required (over-education) will often earn less than individuals with the same level of education working in jobs for which the level is appropriate (adequate education), but more than individuals working in an equivalent job with the level of education actually required. That is, the wage effects of over-education are usually stronger than the wage effects of under-education.

Hartog (1988) shows that the probability of achieving a higher job level is highest for individuals whose earnings gain across job level is greatest. The higher the job level, the higher the compensation demanded by the individual for further increasing complexity. Similarly, at higher wage levels, individuals are less reluctant to take on more demanding jobs. Other authors (Robie, Ryan, Schmieder, Parra, \& Smith, 1998) suggested a positive relationship between job level and job satisfaction. Higher-level jobs tend to be more complex, provide better working conditions, pay, promotion prospects and supervision and carry greater autonomy and responsibility (Cranny, Smith \& Stone, 1992). Additionally, economists have made much progress in understanding that monetary incentives are important, but that there are also powerful non-monetary motives that provide incentives for individuals to perform specific tasks (Fehr \& Falk, 2002; Igalens \& Roussel, 1999). Jobs that are inherently satisfying provide an intrinsic reward to those performing them.

A number of economic and other social science studies on the subjective utility of working have shown that higher levels of education are unambiguously associated with higher levels of satisfaction (Hartog \& Oosterbeek, 1988; Ross \& Van Willingen, 1997). However, there are several investigations that support the negative effects of perceived over-qualification on dimensions of job satisfaction (Hartog, 2000; Johnson \& Johnson, 2000) and that over-schooling negatively affects job satisfaction (Blanchflower \& Oswald, 1992; Clark, 1996; Clark \& Oswald, 1996; Warr, 1992).

As Hartog (2000) pointed out educational mismatches can be explained by differences in the shares of complex jobs and skilled workers. According to assignment theory, allocation is optimal when workers are allocated top-down according to their competencies, whereby the most competent worker is assigned to the most complex job and the least competent worker is assigned to the simplest job. Within this conceptual framework, and taking into account that in our sample all individuals have completed higher education, we tested assignment theory in terms of human capital competencies in addressing the following: 
- To identify which competencies are the most valuable resources for employment (the relationship between competencies and employment is not really clear; however, what is clear is that there is a discrepancy between the acquisition of competencies, e.g. during study, and the requirement for these competencies at a later time period, e.g. for professional work).

- To analyze the incidence of different human capital competencies in graduates' payoff, both in terms of income (monetary payoff) and job satisfaction (nonmonetary payoff).

- To check to what extent the behavior of human capital competencies is similar to formal education in terms of the influence of the mismatch on the individuals' labor situation.

The paper is organized as follows: the next section describes the data; the third section presents the problems that arise from the competencies classification used in this article; the fourth section describes the empirical model; the fifth and sixth sections respectively present the results for income and job satisfaction; and the final section provides conclusions and some implications for policy makers.

\section{Acquired and required competencies}

The data set used in this paper was taken from a major representative survey comparing the situations of European HE graduates. More than 36,000 graduates (roughly 3,000 from each country), holding a first HE degree were surveyed four years after graduation, that is, graduates from 1995 were surveyed in 1999. The study, known as CHEERS (Careers after Higher Education-A European Research Survey), included graduates from 11 European countries: Austria, Czech Republic, Italy, Finland, France, Germany, The Netherlands, Norway, Spain, Sweden and the United Kingdom (Schomburg \& Teichler, in press; Teichler \& Schomburg, in press). For the purposes of our analysis, data from each country were weighted by the proportion of HE students and the population of each country.

The CHEERS survey asked for information on 32 different items relating to demands for and supplies of competencies. Graduates were asked to indicate on an ordered scale ranking from 1 (not at all) to 5 (to a very great extent), the strength of a given competence (the acquired level of competence) at time of graduation and the extent to which this given competence was required in their current work (the required level of competence). The 32 items are presented in Table 1.

Graduates' responses to the question about the acquired level of competence provide a self-assessment of the level of competencies built up during HE; graduates made retrospective judgments in 1999 about their higher education degrees obtained in 1995 (four years after their graduation). Responses to the question about the level of competencies required provide self-reporting measures about their immediate job situations. The use of these criteria allows information to be obtained from the source closest to the actual job situation, and takes account of some specific circumstances, aspects and features. However, compared to the use of grading by job analysts, it lacks uniform instructions and measurements and may produce biased results on several counts. Also, respondents may be tempted to portray a desired situation (for instance, holding down a job that requires a high level of competence) rather than the true situation, or their answers may be influenced by their needs (physical and psychological), values or work attributes. Finally, graduates' 
Table 1 Descriptive statistics for competencies. Europe as a whole (ordered by largest difference)

\begin{tabular}{|c|c|c|c|c|c|}
\hline \multirow[t]{2}{*}{ Items } & \multicolumn{2}{|c|}{ Acquired } & \multicolumn{2}{|c|}{ Required } & \multirow{2}{*}{$\begin{array}{l}\text { Difference } \\
\text { (Acq - Req) }\end{array}$} \\
\hline & Mean & Std. Dev. & Mean & Std. Dev. & \\
\hline Negotiating & 2.58 & 1.05 & 3.66 & 1.15 & -1.08 \\
\hline Planning, coordinating and organizing & 3.11 & 1.05 & 4.11 & 0.95 & -1.00 \\
\hline Taking responsibilities, decisions & 3.38 & 1.02 & 4.23 & 0.88 & -0.85 \\
\hline Time management & 3.30 & 1.04 & 4.14 & 0.87 & -0.84 \\
\hline Computer skills & 2.97 & 1.14 & 3.80 & 1.12 & -0.83 \\
\hline Working under pressure & 3.53 & 1.08 & 4.29 & 0.89 & -0.76 \\
\hline Economic reasoning & 2.75 & 1.14 & 3.50 & 1.20 & -0.75 \\
\hline Leadership & 2.83 & 1.06 & 3.57 & 1.14 & -0.74 \\
\hline Problem-solving ability & 3.62 & 0.90 & 4.30 & 0.79 & -0.68 \\
\hline Oral communication skills & 3.62 & 0.99 & 4.30 & 0.83 & -0.68 \\
\hline Assertiveness, decisiveness, persistence & 3.50 & 0.99 & 4.14 & 0.84 & -0.64 \\
\hline Initiative & 3.51 & 0.98 & 4.11 & 0.89 & -0.60 \\
\hline Working in a team & 3.65 & 1.04 & 4.19 & 0.93 & -0.54 \\
\hline $\begin{array}{l}\text { Understanding complex social, } \\
\text { organizational and technical systems }\end{array}$ & 2.79 & 1.02 & 3.32 & 1.17 & -0.53 \\
\hline Documenting ideas and information & 3.28 & 1.05 & 3.81 & 1.05 & -0.53 \\
\hline Accuracy, attention to detail & 3.70 & 0.98 & 4.14 & 0.86 & -0.44 \\
\hline $\begin{array}{l}\text { Reflective thinking, assessing } \\
\text { one's own work }\end{array}$ & 3.52 & 0.94 & 3.95 & 0.91 & -0.43 \\
\hline Working independently & 3.95 & 0.95 & 4.33 & 0.86 & -0.38 \\
\hline Adaptability & 3.74 & 0.94 & 4.11 & 0.83 & -0.37 \\
\hline Getting personally involved & 3.79 & 0.96 & 4.07 & 0.92 & -0.28 \\
\hline Analytical competencies & 3.68 & 0.91 & 3.95 & 0.96 & -0.27 \\
\hline Cross-disciplinary thinking/knowledge & 3.39 & 0.88 & 3.65 & 1.01 & -0.26 \\
\hline Field-specific knowledge of methods & 3.41 & 1.00 & 3.67 & 1.14 & -0.26 \\
\hline $\begin{array}{l}\text { Tolerance, appreciating of different } \\
\text { points of view }\end{array}$ & 3.70 & 0.95 & 3.96 & 0.92 & -0.26 \\
\hline Loyalty, integrity & 3.83 & 1.05 & 4.06 & 0.93 & -0.23 \\
\hline Written communication skills & 3.85 & 0.90 & 4.06 & 0.96 & -0.21 \\
\hline Critical thinking & 3.76 & 0.94 & 3.90 & 0.96 & -0.14 \\
\hline Power of concentration & 3.95 & 0.85 & 4.05 & 0.84 & -0.10 \\
\hline Broad general knowledge & 3.70 & 0.82 & 3.62 & 1.00 & 0.08 \\
\hline Field-specific theoretical knowledge & 3.82 & 0.93 & 3.68 & 1.13 & 0.14 \\
\hline Learning abilities & 4.18 & 0.76 & 4.03 & 0.90 & 0.15 \\
\hline Foreign language proficiency & 3.06 & 1.11 & 2.90 & 1.38 & 0.16 \\
\hline
\end{tabular}

judgments in assessing their jobs could well be influenced by different work experience from the graduation (1995) to the time of the survey (1999).

On average, graduates reported lower levels of competence than were required in their jobs. However, four items received high ratings in terms of acquired competencies: foreign language proficiency; learning abilities; field-specific theoretical knowledge; and broad general knowledge.

Table 2 presents the differences between acquired and required competencies for each European country. On average, and as expected, the profiles of acquired and required competencies in the Mediterranean countries-Italy, Spain and France-and the rest-Austria, Germany, the Netherlands, United Kingdom, Finland, Sweden, Norway and Czech Republic_-differ. The Mediterranean countries in our sample are characterized by lack of competencies mainly relating to field-specific knowledge, economic reasoning, working under pressure, and computer skills, but good competencies in loyalty and integrity, power of concentration and critical thinking. 


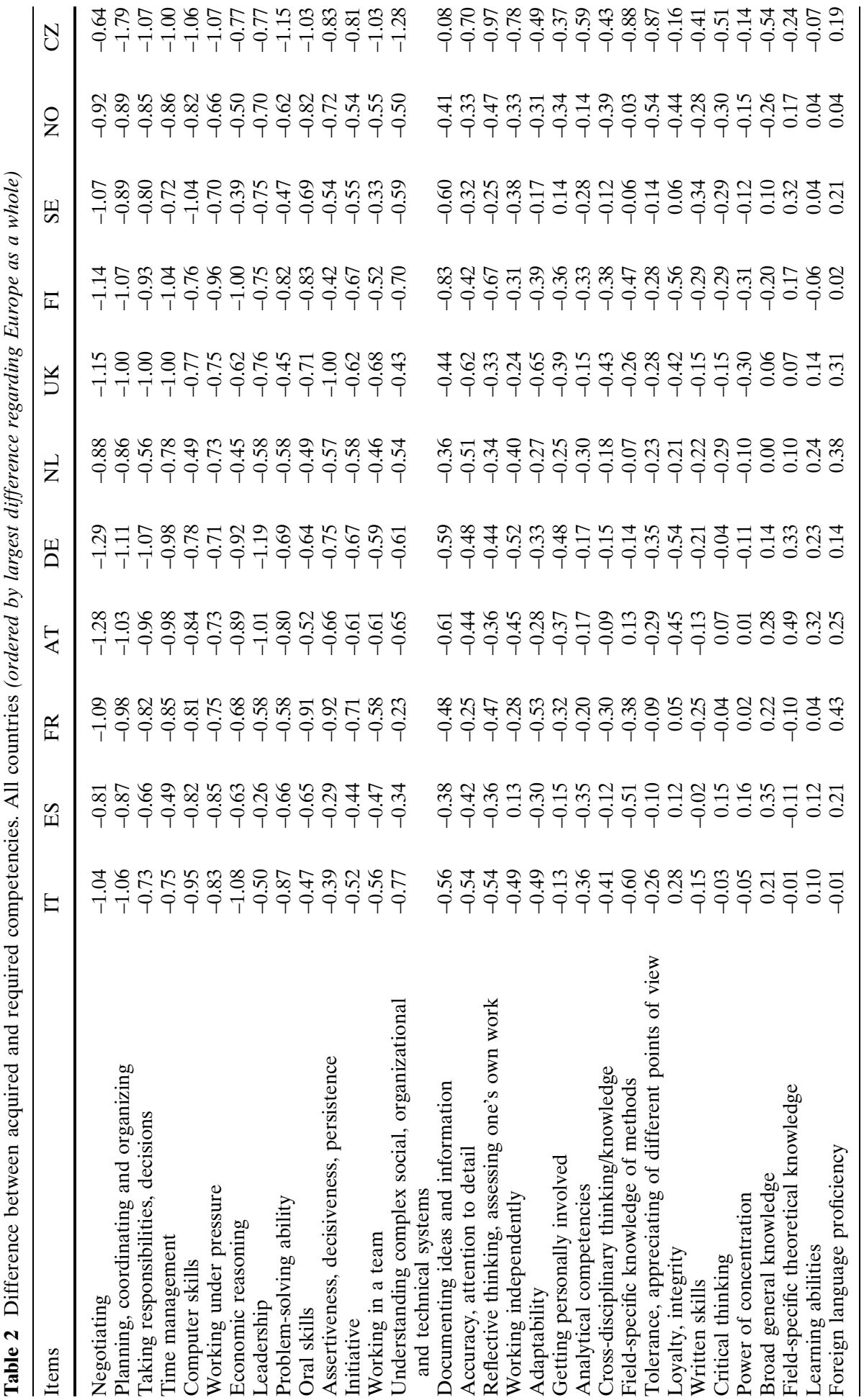


For the non-Mediterranean countries in our sample, Austria and Germany represent one group and the Nordic countries-Finland, Sweden and Norway, together the Netherlands - constitute another. United Kingdom has a more separate position defined by the lack of competencies mainly in assertiveness, decisiveness, persistence, working in a team and adaptability. Finally, the Czech Republic is one with major deficits in competencies related to planning, coordinating and organizing, problem solving ability, documenting ideas and information, and competencies related to broad general knowledge, field-specific knowledge, and learning abilities.

It should be remembered that these results are descriptive and further work, based on multivariate correspondence analysis (Goodman, 1986; Van der Heijden, De Falguerolles, \& De leeuw, 1989), would be needed to check whether the pattern of similarities/disparities found in this study is applicable to each individual country. For reasons of space, we present only data regarding Europe as a whole.

\section{Classification of competencies}

Discussions on the relevance of some human capital competencies compared to others often emphasize the importance of particular knowledge, skills and abilities to carry out an occupation (Hartog, 2001; Rychen \& Salganik, 2003). Some labor market studies relate the skills needed to function in a job and obtain a high salary with what should be achievable from initial education (Oliva, 2003). Other studies have found that higher education students who combine a substantial academic curriculum with various vocational courses do better than students who focus on only one of these two components (Arum \& Shavit, 1995; Bishop, 1995; Kang \& Bishop, 1989). In line with these arguments, it is important for policy to identify a set of relevant competencies associated with successful labor market performance.

Competencies are often classified according to the extent to which their application is related to a particular context, such as a job, a firm, or an occupation. A well-known classification of competencies is Becker's (1980) distinction between general and firm-specific competencies, which Nordhaug (1993) refined and extended by distinguishing between competencies specific to firms (firm-specificity), tasks (task-specificity), and economic sectors (industry-specificity).

Heijke et al. (2002) distinguish three groups of competencies: those acquired in school, which are of direct use in later work; those acquired in school, which facilitate acquisition of new competencies after graduation from school; and those acquired mainly in a working context. Kellermann (2007) classifies competencies into five groups, featuring an "academic personality", general-academic (represented by competence broad general knowledge), scientific-operative (represented by accuracy, attention to detail), personal-professional (represented by field-specific knowledge of methods), social-reflexive (represented by leadership), and physiological-handicraft (represented by manual skills). Bunk (1994) aggregates these competencies into four different groups: specialized, methodological, participative and socio-individual. Other classifications are added depending on the data available (Allen \& Van der Velden, 2001). Thus, there is no general agreement about competency classifications, and economic theory does not provide any clear categorization.

Since competencies are connected with a meaningful connotation, we tried to make the data more transparent and to overcome the multicollinearity problem in the list of the 32 competencies available in our sample. To do this, we applied a 
factor analysis to the list of required competencies, bearing in mind that individuals were more likely to refer to their actual job content. Factor analysis provides orthogonal factor scores that are completely uncorrelated. It does not allow us to attribute cause and effect. It does, however, permit us to classify the competencies into main categories. Principal components analysis (PCA) yielded six factors with an eigenvalue greater than one $(8.84,1.96,1.81,1.40,1.14,1.02)$. These six factors accounted for $50.6 \%$ of the overall variance (i.e., $27.6 \%, 6.1 \%, 5.7 \%, 4.4 \%, 3.6 \%$, $3.2 \%$ of the variance, respectively). These percentages represent the proportion of total unit variance for each item, which is explained by each factor, after allowing for the contribution of the other factors. Factor loadings for each item were used to create an individual factor score for every respondent, that is, the 32 item scores for each respondent were reduced to 6 factor scores (see Appendix Table A1). The six factors were labeled: organizational (F1), specialized (F2), methodological (F3), generic (F4), participative (F5), socio-emotional competencies (F6).

For the first group, F1 (organizational), we found a Croanbach alpha of 0.72; for F2 (specialized) the alpha was 0.75 ; for F3 (methodological) the alpha was 0.72 ; for F4 (generic) the alpha was 0.72 ; for F5 (participative) the alpha was 0.77 ; and for F6 (socioemotional) the alpha was 0.77 . Although there is no generally agreed cut-off, usually a value of alpha of 0.70 or more is seen as acceptable (Nunnally \& Bernstein, 1994).

We defined these factor groups (Table 3 ) as follow. Organizational competencies are held by those who are able to work under pressure, to work independently and with attention to detail. Specialized competencies are held by those who are able to carry out activities and tasks in their field of work in a responsible and competent manner and possess the required knowledge and skills to do so. Methodological competencies are defined as being able to react to problems in a manner that is appropriate, using the procedure expected, and being able to apply experience

Table 3 Categories of competencies

\section{Organizational}

Working under pressure

Accuracy, attention to detail

Time management

Working independently

Power of concentration

\section{Methodological}

Foreign language proficiency

Computers skills

Understanding social,

organizational/technical systems

Documenting ideas and information

Problem-solving ability

Analytical competencies

Learning abilities

\section{Participative}

Planning, coordinating and organizing

Economic reasoning

Negotiating

Assertiveness, decisiveness, persistence

Leadership

Taking responsibilities, decisions

\section{Specialized}

Field-specific theoretical knowledge

Field-specific knowledge of methods

\section{Generic}

Broad general knowledge

Cross-disciplinary thinking/knowledge

Critical thinking

Oral communications skills

Written communications skills

Socio-emotional competencies

Reflective thinking, assessing one's own work

Working in a team

Initiative

Adaptability

Getting personally involved

Loyalty, integrity

Tolerance, appreciating of different point of view 
gained to find sensible solutions to other problems. Generic competencies can be defined as those competencies that can be applied across a broad range of contexts. This indicates that generic competencies imply more than just general knowledge in the strict sense; it also includes critical thinking and oral and written communications skills. Participative competencies are held by those who are able to contribute towards constructing the working environment in their workplace and beyond, who can plan ahead, assume tasks, take decisions and are willing to assume responsibility. Finally, individuals who are able to work cooperatively with others and who show team-oriented behavior and interpersonal understanding are described as having socio-emotional competencies.

\section{Empirical model}

In addition to identification of the most important acquired and required competencies, we are particularly interested in the returns on human capital competencies in the labor market, in terms of both income and job satisfaction. To obtain the returns for income, we applied job-matching theory, which expects that more demanding jobs will be result in higher incomes, income premiums for surpluses, and income penalties for deficits in competencies. For job satisfaction, we performed the same analysis. Here we expected different results: working in a job that requires a high level of competencies has a positive effect on job occupant's satisfaction, but surpluses in competencies are an important cause of job dissatisfaction, while the effects of deficits are ambiguous depending on the individual challenge. As mentioned above, we applied factor analysis to the required competencies. This yielded six factors. To define deficits and surpluses, we used the same factor loadings for acquired competencies and calculated the difference. As both acquired and required competencies were standardized before applying factor analysis, the resulting differences refer to relative differences.

To analyze the effects of these six competence-categories requirements, surpluses, and deficits related to graduates' income and job satisfaction, we estimated a conventional earnings regression for income using OLS estimation, and an ordered probit regression for job satisfaction to reflect the ordinal character of the answers on job satisfaction scores. In our survey, higher education graduates were asked: Altogether, to what extent are you satisfied with your current job? Respondents could choose from five rankings from 1 (very dissatisfied) to 5 (very satisfied). Selfassessments of job satisfaction indicate how people value the whole package of both monetary and non-monetary returns from their jobs, according to their personal preferences. Survey responses for job satisfaction have been used in economic analysis as proxy data for utility from work, with job satisfaction, in its turn, being a key determinant of total well-being for working individuals (Van Praag, 1991).

To facilitate a comparison of these effects, two specifications were estimated. First, we assessed a model containing indicators of the required level of competencies, with control variables for personal characteristics, job characteristics, occupational titles, fields of study, job in own domain, dummies for each country and for the distinction between university institutions and other HE institutions (Model I). Then, in order to ascertain to what extent surpluses and/or deficits in competencies have effects on income and job satisfaction, we added indicators of mismatches according to the competencies required for the job (Model II). 
We used working hours and size of firms as job attributes. In public sector employment, full-time jobs and permanent contracts have specific characteristics that many people consider desirable, thus we also included a dummy variable for each. The six dummies representing the occupational titles were: legislators, senior officials and managers; professionals; technicians and associate professionals; clerks; service workers and, shop and market workers; skilled agricultural and fishery workers, and elementary occupations.

In addition to the effects of a mismatch between acquired and required level of competencies, we took into account the effects of graduating in a specific field of study. We used dummies for eight different fields of study: Education, Humanities, Social Sciences, Law, Natural Sciences, Mathematics, Medical Sciences and Engineering. We also defined a dummy for those working in their own field-specific educational domain. Job in own domain is measured as holding a position for which the own field of study is by far the best, or for which a related field of study could provide the same sort of grounding. Personal characteristics such as age and gender were included as control variables.

We made a distinction between university institutions and other HE institutions to test for possible differences between the effects of both types of institutions on the careers of graduates. To provide a more detailed analysis, we used dummies for each European country included in our sample: Austria, Czech Republic, Italy, Finland, France, Germany, The Netherlands, Norway, Spain, Sweden and the United Kingdom. Descriptive statistics for all these variables are reported in the Appendix (see Table A2).

\section{Effects of competencies on income}

Table 4 shows the results for a conventional earnings regression (natural logarithm of income). Model I shows that $39 \%$ of the income differences can be explained by the variables in the model. Although this percentage seems low, the relative homogeneity of the group in terms of basic human capital aspects should be borne in mind. There were in fact differences among the competence-categories considered. We observed that participative and methodological competencies seemed to be much more important than other competencies for explaining income differences. One standard deviation increase in the required level of participative competencies yielded an income increase of some $6 \%$, and a similar increase in the required level of methodological competencies yielded an income increase of some $4 \%$. Socio-emotional and generic competencies had a similar, but smaller effect on income increase. With respect to specialized competencies, income analysis shows that the required level did not have a significant effect. This result must be interpreted with care bearing in mind that in our analysis we used occupational titles as control variables. A separate analysis (not shown here) which did not consider occupational titles showed a significant positive effect of specialized competencies on income. Therefore, the analysis presented in Table 4 indicates that the effect of specialized competencies on job performance is mediated by type of job. Finally, organizational competencies had a negative effect. This might indicate that these competencies are not rewarded in the first years of professional careers. 
Table 4 OLS parameter estimates for annual gross income. European countries

\begin{tabular}{|c|c|c|c|c|}
\hline & \multicolumn{2}{|l|}{ Model I } & \multicolumn{2}{|l|}{ Model II } \\
\hline & Coeff. & $t$-values & Coeff. & $t$-values \\
\hline \multicolumn{5}{|l|}{ Competencies required } \\
\hline Organizational & $-0.012 *$ & -4.056 & $-0.013^{*}$ & -3.335 \\
\hline Specialized & -0.001 & -0.380 & $-0.008 * * *$ & -1.846 \\
\hline Methodological & $0.040^{*}$ & 12.752 & $0.056^{*}$ & 13.702 \\
\hline Generic & $0.018^{*}$ & 5.813 & 0.003 & 0.746 \\
\hline Participative & $0.052^{*}$ & 16.661 & $0.046^{*}$ & 11.329 \\
\hline Socio-emotional & $0.023^{*}$ & 7.524 & $0.016^{*}$ & 4.108 \\
\hline \multicolumn{5}{|l|}{ Surplus of competencies } \\
\hline Organizational & - & - & -0.003 & -0.598 \\
\hline Specialized & - & - & $-0.009 * * *$ & -1.745 \\
\hline Methodological & - & - & $0.013^{* *}$ & 2.247 \\
\hline Generic & - & - & $-0.020^{*}$ & -4.020 \\
\hline Participative & - & - & -0.006 & -1.060 \\
\hline Socio-emotional & - & - & $-0.017 *$ & -3.296 \\
\hline \multicolumn{5}{|l|}{ Deficit of competencies } \\
\hline Organizational & - & - & 0.002 & 0.419 \\
\hline Specialized & - & - & 0.005 & 1.101 \\
\hline Methodological & - & - & $-0.036^{*}$ & -6.098 \\
\hline Generic & - & - & $0.014 *$ & 2.552 \\
\hline Participative & - & - & 0.007 & 1.588 \\
\hline Socio-emotional & - & - & 0.003 & 0.562 \\
\hline \multicolumn{5}{|l|}{ Personal characteristics } \\
\hline Female & $-0.069 *$ & -11.463 & $-0.069 *$ & -11.347 \\
\hline Age & $0.011 *$ & 7.815 & $0.012 *$ & 8.236 \\
\hline \multicolumn{5}{|l|}{ Job characteristics } \\
\hline Hours worked per week & $0.259^{*}$ & 18.999 & $0.259 *$ & 18.974 \\
\hline Private sector & $0.081 *$ & 12.212 & $0.079 *$ & 11.964 \\
\hline Small firm & $-0.144 *$ & -20.615 & $-0.144 *$ & -20.607 \\
\hline Full-time job & $0.263^{*}$ & 22.569 & $0.261 *$ & 22.469 \\
\hline Permanent contract & $0.126^{*}$ & 17.166 & $0.125^{*}$ & 17.075 \\
\hline \multicolumn{5}{|l|}{ Occupational titles } \\
\hline $\begin{array}{l}\text { Legislators, senior official } \\
\text { and managers }\end{array}$ & $0.188^{*}$ & 16.207 & $0.183^{*}$ & 15.780 \\
\hline \multicolumn{5}{|l|}{ (ref. Elementary occupations) } \\
\hline Professionals & $0.132 *$ & 15.324 & $0.130^{*}$ & 15.002 \\
\hline $\begin{array}{l}\text { Technicians and associate } \\
\text { professionals }\end{array}$ & $0.080^{*}$ & 7.546 & $0.080^{*}$ & 7.486 \\
\hline Clerks & -0.018 & -1.181 & -0.020 & -1.310 \\
\hline Service workers & -0.020 & -0.860 & -0.023 & -0.991 \\
\hline \multicolumn{5}{|l|}{ Field of studies } \\
\hline Education (ref. Engineering) & $-0.081 *$ & -5.889 & $-0.067 *$ & -4.810 \\
\hline Humanities & $-0.117 *$ & -11.194 & $-0.105^{*}$ & -9.830 \\
\hline Social Sciences & $-0.030^{*}$ & -3.790 & $-0.026^{*}$ & -3.227 \\
\hline Law & $-0.098^{*}$ & -8.069 & $-0.085^{*}$ & -6.906 \\
\hline Natural Sciences & $-0.079 *$ & -7.115 & $-0.074 *$ & -6.648 \\
\hline Mathematics & $0.095^{*}$ & 7.330 & $0.085^{*}$ & 6.504 \\
\hline Medical Sciences & $0.045^{*}$ & 3.664 & $0.056^{*}$ & 4.512 \\
\hline Universities vs. H.E. Institutions & $0.038^{*}$ & 5.531 & $0.038^{*}$ & 5.479 \\
\hline Job in own domain & $0.058^{*}$ & 8.705 & $0.054 *$ & 8.082 \\
\hline Intercept & $1.648^{*}$ & 25.848 & $1.646^{*}$ & 25.602 \\
\hline Observations & 24,414 & & 24,414 & \\
\hline Adjusted R-squared & 0.39 & & 0.40 & \\
\hline
\end{tabular}

$* p \leq 0.01 ; * * p \leq 0.05 ; * * * p \leq 0.10$ (effects of country dummies not shown) 
In Model II, indicators of competencies mismatches were added to the earning equation. This slightly improves the model fit, resulting in an adjusted R-squared of 0.40 . We observed that the weight of some competencies increased, e.g. methodological competencies, and others decreased, e.g. participative, generic and socioemotional competencies.

In terms of the effect of the mismatches, there was a significant positive effect of surpluses in methodological competencies, which confirms the prediction that methodological competence pay off even when they were not required. The predicted negative effect of deficits in this competence was also observed. However, the predictions of assignment theory and the results obtained in earlier research, that the effects of surpluses in competencies are considerably greater than those for deficits, were not confirmed by our results. Each additional standard deviation surplus in methodological competencies yielded an income increase of some 1\%. Each additional standard deviation deficit in methodological competencies led to a decrease in income of $3 \%$.

Other results were the reverse of what we might expect on the basis of assignment theory-wages premiums for surplus, and wage penalties for deficits in competencies. Having a higher level of generic, socio-emotional and specialized competencies than the job required had a negative effect on income. This is likely to be the result of the presence of strong deficits in other competencies not considered in our analysis, e.g. extra-curricula competencies, especially if these deficits in unmeasured competencies are strongly correlated with surpluses in measured competencies. In the case of specialized competencies in particular, this might be a valid explanation of the negative effect of a surplus. If someone works in a job outside his/her field of study, then he/she will experience a surplus of specialized competencies and a deficit of the competencies needed in the actual area of work. If these other competencies are not measured, then the surplus of specialized competencies will show a negative sign. On the other hand, surpluses and deficits in participative and organizational competencies appeared to have no effect on income.

The results for the rest of the key variables considered in both Model I and Model II were similar. Consistent with other work in this area, we found that female graduates earned less than their male counterparts, and that age (capturing work experience) had a positive effect. On the other hand, those working in the private sector, or on permanent contracts, earned more than those working in the public sector or on temporary contracts. Positive effects were also found for fulltime jobs and number of hours worked, and negative effects for those working in small firms.

With respect to occupational titles, both models provide evidence suggesting that individuals working in more demanding jobs achieve higher incomes. Legislators, senior officials, managers, professionals, technicians and associate professionals earned more than their counterparts in less demanding occupations. When we explore the segmentation of different educational fields, we note that graduates in Education, Humanities, Social Science, Law and Natural Sciences earned less than the reference category (Engineering). However, Mathematics (data processing and computer specialists included) and Medical Sciences graduates earned more. It might be expected that there is a high likelihood that graduates from Mathematics, Medical Sciences and Engineering will work within their own educational domains and that therefore they will benefit from an income premium (due to their good competence match). The results in Table 4 show that working within one's particular 
knowledge domain increases income by $5 \%$. Finally, having received a university education rather than being educated at another type of $\mathrm{HE}$ institution, yields an increase in income of around $4 \%$.

\section{Effects of competencies on job satisfaction}

The effects of competency mismatches on job satisfaction are shown in Table 5. To reflect the ordinal character of the responses about job satisfaction, we used an ordered probit model. Maximum-likelihood estimation of the models was carried out using the Newton-Raphson algorithm based on second derivates (Green, 1997). To facilitate a comparison of income effects, the same set of independent variables was included. Annual gross income was also included as an additional control variable.

Table 5 Ordered probit estimates for job satisfaction. European countries

\begin{tabular}{|c|c|c|c|c|}
\hline & \multicolumn{2}{|l|}{ Model I } & \multicolumn{2}{|l|}{ Model II } \\
\hline & Coeff. & Sig. & Coeff. & Sig. \\
\hline \multicolumn{5}{|l|}{ Competencies required } \\
\hline Organizational & $0.103^{*}$ & 13.126 & $0.086^{*}$ & 8.887 \\
\hline Specialized & $0.129 *$ & 15.876 & $0.114 *$ & 10.350 \\
\hline Methodological & $0.069 *$ & 8.527 & $0.077 *$ & 7.415 \\
\hline Generic & $0.194 *$ & 24.831 & $0.132 *$ & 12.847 \\
\hline Participative & $0.094 *$ & 11.830 & $0.103 *$ & 9.943 \\
\hline Socio-emotional & $0.180^{*}$ & 22.868 & $0.151 *$ & 15.445 \\
\hline \multicolumn{5}{|l|}{ Surplus of competencies } \\
\hline Organizational & - & - & $-0.071 *$ & -5.372 \\
\hline Specialized & - & - & -0.003 & -0.245 \\
\hline Methodological & - & - & 0.022 & 1.520 \\
\hline Generic & - & - & $-0.102 *$ & -8.167 \\
\hline Participative & - & - & 0.017 & 1.272 \\
\hline Socio-emotional & - & - & $-0.052 *$ & -3.925 \\
\hline \multicolumn{5}{|l|}{ Deficit of competencies } \\
\hline Organizational & - & - & -0.014 & -1.099 \\
\hline Specialized & - & - & $0.035^{*}$ & 2.974 \\
\hline Methodological & - & - & 0.001 & 0.006 \\
\hline Generic & - & - & $0.038^{*}$ & 2.737 \\
\hline Participative & - & - & -0.010 & -0.910 \\
\hline Socio-emotional & - & - & $0.022 * * *$ & 1.871 \\
\hline \multicolumn{5}{|l|}{ Personal characteristics } \\
\hline Female & -0.008 & -0.536 & -0.010 & -0.636 \\
\hline Age & $-0.037 *$ & -10.137 & $-0.037^{*}$ & -9.965 \\
\hline \multicolumn{5}{|l|}{ Job characteristics } \\
\hline Annual gross income & $0.325^{*}$ & 19.867 & $0.319 *$ & 19.442 \\
\hline Hours worked per week & 0.031 & 0.894 & 0.035 & 0.996 \\
\hline Private sector & $-0.144 *$ & -8.464 & $-0.143^{*}$ & -8.406 \\
\hline Small firm & $0.106^{*}$ & 5.904 & $0.103^{*}$ & 5.689 \\
\hline Full-time job & 0.026 & 0.873 & 0.024 & 0.800 \\
\hline Permanent contract & $0.115^{*}$ & 6.135 & $0.111 *$ & 5.905 \\
\hline
\end{tabular}


Table 5 continued

\begin{tabular}{|c|c|c|c|c|}
\hline & \multicolumn{2}{|l|}{ Model I } & \multicolumn{2}{|l|}{ Model II } \\
\hline & Coeff. & Sig. & Coeff. & Sig. \\
\hline \multicolumn{5}{|l|}{ Occupational titles } \\
\hline $\begin{array}{l}\text { Legislators, senior official } \\
\text { and managers } \\
\text { (ref. Elementary occupations) }\end{array}$ & $0.153^{*}$ & 5.153 & $0.150 *$ & 5.041 \\
\hline Professionals & $0.172 *$ & 7.769 & $0.172 *$ & 7.771 \\
\hline $\begin{array}{l}\text { Technicians and } \\
\text { associate professionals }\end{array}$ & $0.106^{*}$ & 3.911 & $0.109 *$ & 4.025 \\
\hline Clerks & $-0.114 *$ & -3.007 & $-0.116 *$ & -3.071 \\
\hline Service workers & 0.043 & 0.729 & 0.043 & 0.721 \\
\hline \multicolumn{5}{|l|}{ Field of studies } \\
\hline Education (ref. Engineering) & -0.026 & -0.727 & -0.005 & -0.154 \\
\hline Humanities & $-0.081 *$ & -3.011 & -0.032 & -1.178 \\
\hline Social Sciences & $-0.067 *$ & -3.244 & $-0.062 *$ & -2.965 \\
\hline Law & $-0.137 *$ & -4.402 & $-0.118 *$ & -3.726 \\
\hline Natural Sciences & 0.036 & 1.269 & 0.045 & 1.600 \\
\hline Mathematics & $0.143^{*}$ & 4.267 & $0.129 *$ & 3.838 \\
\hline Medical Sciences & $-0.089 *$ & -2.850 & $-0.077 *$ & -2.452 \\
\hline Universities vs. H.E. Institutions & $0.107 *$ & 6.054 & $0.117 *$ & 6.600 \\
\hline Job in own domain & $0.223^{*}$ & 13.071 & $0.214^{*}$ & 12.459 \\
\hline Observations & 24,414 & & 24,414 & \\
\hline$L R \chi 2(38) ; L R \chi 2(50)$ & 4,259.49 & & 4,411.07 & \\
\hline Log likelihood & $-30,991.35$ & & $-30,910.73$ & \\
\hline
\end{tabular}

$* p \leq 0.01 ; * * p \leq 0.05 ; * * * p \leq 0.10$ (effects of country dummies not shown)

Model I shows that job satisfaction was strongly influenced by the required level of competencies. We observe that a high requirement in terms of generic, socioemotional, specialized, organizational and participative competencies had a positive effect on job satisfaction.

Again, Model II includes indicators for mismatches in competencies. And again, an accurate match between competencies acquired and competencies required in the job, increased job satisfaction significantly. As expected, graduates who reported a surplus of competencies had much less job satisfaction than those with the right competencies for the job. The exception was a surplus in specialized, methodological and participative competencies. On the other hand, deficits in generic, specialized and socio-emotional competencies increased satisfaction, probably due to the fact that these deficits were viewed as a personal challenge.

The results for the remaining control variables were similar for both models. As predicted by the conventional literature, age had a negative effect (Clark \& Oswald, 1996). Also, as might be expected, income had a fairly strong effect on job satisfaction, and graduates working in small firms on permanent contracts also reported reasonable job satisfaction. Public sector workers reported higher levels of job satisfaction than private sector ones.

With respect to occupational titles, both models provide evidence that individuals working in more complex jobs received more satisfaction. Legislators, senior officials, managers, professionals, technicians and associate professionals were more satisfied in their work than their counterparts in less senior occupations. It could be 
said that high-level jobs tend to be more complex and have better working conditions, pay, promotion prospects, supervision, autonomy and responsibility, and all these characteristics are associated with job satisfaction.

On the other hand, graduates in Humanities, Medical Sciences, Social Sciences and Law reported less job satisfaction with respect to the reference category (Engineering). Mathematics graduates were the most satisfied with their jobs. Finally, a university education rather than another type of $\mathrm{HE}$, and working inside one's own domain of expertise increased the level of job satisfaction.

\section{Conclusions}

In this paper we analyzed the relationship between the payoffs from the required, surplus, and deficit human capital competencies in terms of both income (monetary payoff) and job satisfaction (non-monetary payoff) of graduates. In assignment theory the concepts of educational and competencies mismatches are assumed to be closely related: educational mismatches imply competency mismatches, which in turn have an effect on income. Due to the fact that all individuals, in our sample had completed HE, we analyzed the incidence of different human capital competencies in graduates' payoffs. Surpluses and deficits in competencies were measured by asking graduates to evaluate the job they held in terms of the level of competencies they thought was required to perform them adequately compared to their actual acquired level.

Six different categories of competencies were explored, namely organizational, specialized, methodological, generic, participative and socio-emotional competencies to give a more detailed analysis of the different roles and payoffs of the competencies in the labor market. Other variables, such as personal characteristics, job characteristics, occupational titles, field of study, job in own domain and the distinction of graduates from university institutions versus those from other HE institutions, were also considered. Control variables for the 11 European countries in our sample were also taken into account.

The results provide strong support for the assumption that the match between individual human capital competencies and the characteristics of the job does matter. Our findings from the income analysis, suggest that those jobs with a high requirement for participative and methodological competencies were the best paid and that jobs with a high requirement for organizational competencies were the worst paid. Specialized competencies had an indirect effect in their allocation to professional jobs. In short, we observe that monetary rewards depend most on competencies related to the capacity of the individual to manage a complex situation with leadership and personal involvement. Attitudes towards work (rather than knowledge) were the characteristics that received the highest financial recognition in the labor market for young graduates. Our results for job satisfaction support the statement that working in a job that requires a high level of competencies has a positive effect on the job-holder's satisfaction.

The analysis of competency mismatches shows that a surplus of methodological competencies has a positive effect on income, and a deficit has a negative effect on income. This was the only case that behaved as predicted by assignment theory-wage premiums for surpluses and wage penalties for deficits in competencies. The behavior in terms of the remaining competencies was different and 
non-systematic. Of particular interest was the case of generic competencies: a surplus was penalized and a deficit awarded. One explanation for this could be that assignment theory does not hold for competencies (all or part of them). Another possibility is that, because we were analyzing jobs occupied by recent graduates, salaries were more related to the job than to the individual's actual performance. In terms of job satisfaction, we found that competencies surplus was an important cause of job dissatisfaction, the exception being methodological, specialized and participative competencies. Deficits in generic, specialized and socio-emotional competencies apparently increase satisfaction. This is likely due to the types of jobs where the requirements for these competencies is high (scientists, medicine, and so on), and to the personal challenge implied.

Consistent with earlier work in this area, we found that female graduates earned less, but were as satisfied in their jobs as their male counterparts. In addition, young European graduates with permanent and full-time jobs in the private sector or in large firms earned more, although their preference was for public sector jobs and work in small firms. All round, a good salary was the main factor involved in increased job satisfaction. High-level jobs were related to both high-income and high levels of satisfaction. Fields such as Mathematics and Engineering generated high incomes and job satisfaction. Working inside one's particular domain of expertise and having a university education rather than being educated at some other type of $\mathrm{HE}$ institution increased both income and job satisfaction.

We can conclude from our results that European HE systems need to have more awareness with the realities of the labor market. Further research on competencies will increase understanding about how the graduate labor market works. Both the titles and content of occupations are changing. Traditionally, at least in most European countries, theoretical and specific knowledge have been the key to high professional positions, related to a HE diploma. A new and more dynamic labor market, and the massive presence of HE graduates in the labor market, has created a new situation in which these competencies are not so much in demand (taking monetary rewards as a proxy for demand) in the labor market. The new situation requires individuals with participative, methodological and socio-emotional competencies. Enhancing these competencies in the educational process requires an approach that is different from what has traditionally been offered by HE institutions, an approach that is focused on active learning, stimulation of relationships and cooperation of individuals, promoting multidisciplinary approaches, and so on. In summary, current social demand requires a different style learning process that is far removed from the traditional methods based on passive accumulation of knowledge. In addition, it should be kept in mind that the diversity pattern found in the profiles of the acquired and required level of competencies among the European countries analyzed in our sample demonstrates that these changes to the learning process will need policies tailored to individual country situations.

Thus, our results open a number of interesting areas for discussion: What is the relative importance of specific as opposed to more generic competencies? Are different competencies required during the transition from education to work than in later career stages? What are the competencies that graduates need for quick productivity returns, and which ones are more important for longer-term employability? What are the implications for the curriculum? These questions are of great 
importance, not only from a scientific point of view, but also to enable a more effective and efficient organization of education.

\section{Appendix}

Table A1 Rotated factor matrix for required competencies

\begin{tabular}{|c|c|c|c|c|c|c|}
\hline Items & F1 & $\mathrm{F} 2$ & F3 & $\mathrm{F} 4$ & F5 & F6 \\
\hline Working under pressure & 0.49 & 0.03 & 0.18 & -0.07 & 0.43 & 0.11 \\
\hline Accuracy, attention to detail & 0.71 & 0.14 & 0.13 & 0.01 & 0.06 & 0.07 \\
\hline Time management & 0.52 & 0.02 & 0.07 & 0.07 & 0.42 & 0.10 \\
\hline Working independently & 0.48 & 0.11 & 0.06 & 0.25 & 0.23 & 0.02 \\
\hline Power of concentration & 0.66 & 0.17 & 0.14 & 0.15 & 0.05 & 0.22 \\
\hline Field-specific theoretical knowledge & 0.10 & 0.85 & -0.01 & 0.10 & 0.01 & 0.02 \\
\hline Field-specific knowledge of methods & 0.07 & 0.86 & 0.07 & 0.06 & 0.05 & 0.06 \\
\hline Foreign language proficiency & 0.03 & -0.05 & 0.54 & 0.12 & -0.02 & 0.04 \\
\hline Computer skills & 0.11 & -0.06 & 0.71 & 0.05 & 0.08 & -0.02 \\
\hline $\begin{array}{l}\text { Understanding social, organizational/technical } \\
\text { systems }\end{array}$ & -0.07 & 0.07 & 0.52 & 0.23 & 0.37 & 0.04 \\
\hline Documenting ideas and information & 0.19 & 0.17 & 0.50 & 0.23 & 0.21 & 0.18 \\
\hline Problem-solving ability & 0.30 & 0.30 & 0.41 & 0.08 & 0.31 & 0.21 \\
\hline Analytical competencies & 0.26 & 0.37 & 0.53 & 0.10 & 0.09 & 0.18 \\
\hline Learning abilities & 0.36 & 0.24 & 0.42 & 0.18 & -0.03 & 0.31 \\
\hline Broad general knowledge & 0.04 & 0.08 & 0.06 & 0.72 & 0.17 & 0.07 \\
\hline Cross-disciplinary thinking/knowledge & -0.03 & 0.19 & 0.21 & 0.67 & 0.20 & 0.05 \\
\hline Critical thinking & 0.32 & 0.22 & 0.13 & 0.39 & 0.08 & 0.38 \\
\hline Oral communication skills & 0.24 & 0.02 & 0.01 & 0.50 & 0.27 & 0.31 \\
\hline Written communication skills & 0.34 & 0.07 & 0.26 & 0.54 & 0.06 & 0.13 \\
\hline Planning, coordinating and organizing & 0.11 & 0.06 & 0.31 & 0.23 & 0.58 & 0.14 \\
\hline Economic reasoning & 0.09 & -0.06 & 0.36 & 0.04 & 0.59 & -0.07 \\
\hline Negotiating & 0.14 & -0.08 & 0.07 & 0.15 & 0.67 & 0.12 \\
\hline Assertiveness, decisiveness, persistence & 0.41 & 0.10 & -0.03 & 0.19 & 0.43 & 0.31 \\
\hline Leadership & -0.03 & 0.10 & 0.03 & 0.17 & 0.65 & 0.33 \\
\hline Taking responsibilities, decisions & 0.19 & 0.17 & -0.07 & 0.19 & 0.61 & 0.32 \\
\hline Reflective thinking, assessing one's own work & 0.30 & 0.27 & 0.14 & 0.30 & 0.13 & 0.40 \\
\hline Working in a team & -0.01 & 0.06 & 0.22 & -0.01 & 0.21 & 0.65 \\
\hline Initiative & 0.25 & 0.09 & 0.13 & 0.21 & 0.41 & 0.44 \\
\hline Adaptability & 0.19 & -0.01 & 0.08 & -0.02 & 0.19 & 0.67 \\
\hline Getting personally involved & 0.35 & 0.10 & -0.07 & 0.23 & 0.24 & 0.37 \\
\hline Loyalty, integrity & 0.28 & -0.04 & -0.09 & 0.17 & 0.13 & 0.44 \\
\hline $\begin{array}{l}\text { Tolerance, appreciating of different } \\
\text { points of view }\end{array}$ & 0.09 & 0.08 & -0.03 & 0.34 & 0.15 & 0.61 \\
\hline
\end{tabular}

Table A2 Descriptive statistics

\begin{tabular}{lrlrr}
\hline Variable & Mean & Std. Dev. & Min. & Max. \\
\hline Organizational & 0.01 & 0.93 & -6.01 & 3.43 \\
Specialized & 0.01 & 0.91 & -3.72 & 2.54 \\
Methodological & 0.01 & 0.93 & -4.82 & 3.21 \\
Generic & -0.01 & 0.91 & -4.99 & 4.04 \\
Participative & 0.02 & 0.92 & -4.59 & 4.43 \\
Socio-emotional & -0.03 & 0.93 & -6.04 & 3.42 \\
\hline
\end{tabular}


Table A2 continued

\begin{tabular}{|c|c|c|c|c|}
\hline Variable & Mean & Std. Dev. & Min. & Max. \\
\hline Surplus-organizational & 0.42 & 0.65 & 0 & 6.25 \\
\hline Surplus-specialized & 0.44 & 0.72 & 0 & 6.25 \\
\hline Surplus-methodological & 0.39 & 0.50 & 0 & 6.00 \\
\hline Surplus_-generic & 0.42 & 0.71 & 0 & 7.28 \\
\hline Surplus_participative & 0.41 & 0.64 & 0 & 5.67 \\
\hline Surplus-socio-emotional & 0.40 & 0.65 & 0 & 6.98 \\
\hline Deficit-organizational & 0.36 & 0.61 & 0 & 6.44 \\
\hline Deficit-specialized & 0.42 & 0.67 & 0 & 4.95 \\
\hline Deficit-methodological & 0.33 & 0.54 & 0 & 5.11 \\
\hline Deficit-generic & 0.37 & 0.59 & 0 & 5.17 \\
\hline Deficit-participative & 0.48 & 0.76 & 0 & 5.87 \\
\hline Deficit-socio-emotional & 0.39 & 0.66 & 0 & 6.27 \\
\hline Female & 0.50 & 0.50 & 0 & 1 \\
\hline Age & 29.14 & 2.42 & 26 & 35 \\
\hline Hours worked per week & 37.20 & 7.33 & 10 & 60 \\
\hline Private sector & 0.70 & 0.46 & 0 & 1 \\
\hline Size firm: small & 0.22 & 0.41 & 0 & 1 \\
\hline Full-time job & 0.89 & 0.31 & 0 & 1 \\
\hline Permanent contract & 0.78 & 0.42 & 0 & 1 \\
\hline $\begin{array}{l}\text { Legislators, senior official } \\
\text { and managers }\end{array}$ & 0.09 & 0.28 & 0 & 1 \\
\hline Professionals & 0.54 & 0.50 & 0 & 1 \\
\hline $\begin{array}{l}\text { Technicians and associate } \\
\text { professionals }\end{array}$ & 0.15 & 0.36 & 0 & 1 \\
\hline Clerks & 0.03 & 0.18 & 0 & 1 \\
\hline Service workers & 0.01 & 0.10 & 0 & 1 \\
\hline Elementary workers & 0.18 & 0.11 & 0 & 1 \\
\hline Education & 0.05 & 0.23 & 0 & 1 \\
\hline Humanities & 0.12 & 0.33 & 0 & 1 \\
\hline Social Sciences & 0.31 & 0.46 & 0 & 1 \\
\hline Law & 0.07 & 0.26 & 0 & 1 \\
\hline Natural Sciences & 0.09 & 0.29 & 0 & 1 \\
\hline Mathematics & 0.06 & 0.23 & 0 & 1 \\
\hline Medical Sciences & 0.08 & 0.27 & 0 & 1 \\
\hline Engineering & 0.22 & 0.41 & 0 & 1 \\
\hline Universities & 0.76 & 0.42 & 0 & 1 \\
\hline Job in own domain & 0.74 & 0.44 & 0 & 1 \\
\hline
\end{tabular}

\section{References}

Acemoglu, D. (1998). Why do technologies complement skills? Directed technical change and wage inequality. Quarterly Journal of Economics, 113, 1055-1089.

Acemoglu, D., \& Pischke, J. S. (1998). Why do firms train? Theory and evidence. The Quarterly Journal of Economics, 113(1), 79-119.

Allen, J., \& Van der Velden, R. (2001). Educational mismatches versus skill mismatches: Effects on wages, job satisfaction and on-the-job search. Oxford Economic Papers, 53(3), 434-452.

Arum, R., \& Shavit, Y. (1995). Secondary vocational education and the transition from school to work. Sociology of Education, 68, 187-204.

Autor, D. H., Katz, L. F., \& Krueger, A. B. (1998). Computing inequality: Have computers changed the labor market? Quarterly Journal of Economics, 113, 1169-1213.

Barro, J. M., \& Loewenstein, M. A. (1985). On employer specific information and internal labor markets. Southern Economic Journal, 52, 431-445. 
Becker, G. S. (1964). Human capital - a theoretical and empirical analysis, with special reference to education. New York: National Bureau of Economic Research, Columbia University Press.

Becker, G. S. (1980). Human capital, a theoretical and empirical analysis with special reference to education. Chicago/London: The University of Chicago Press.

Belfield, C. R., Bullock, A. D., \& Fielding, A. (1999). Graduates' views on the contribution of their higher education to their general development: A retrospective evaluation for the United Kingdom. Research in Higher Education, 40(4), 409-438.

Berman, E., Bound, J., \& Machin, S. (1998). Implications of skill-biased technological change: International evidence. Quarterly Journal of Economics, 113, 1245-1279.

Bishop, J. H. (1995). Vocational education and at-risk youth in the United States. Vocational Training European Journal, 6, 34-42.

Blanchflower, D. G., \& Oswald, A. J. (1992). Entrepreneurship, happiness and supernormal returns: Evidence from Britain and the US. NBER Working Paper 4228, Cambridge, MA.

Bradley, S., \& Nguyen, A. N. (2004). The school to work transition. In G. Johnes \& J. Johnes (Eds.), International handbook of education economics (chap. 14). Edward Elgar.

Brown, J. (1989). Why do wages increase with tenure? On the job training and life cycle wage growth observed within firms. American Economic Review, 79, 971-991.

Buchel, F. (2002). The effects of overeducation on productivity in Germany-the firms' viewpoint. Economics of Education Review, 21, 263-275.

Bunk, G. P. (1994). Teaching competence in initial and continuing vocational training in the Federal Republic of Germany. Vocational Training European Journal, 1, 8-14.

Busato, V. V., Prins, F. J., Elshout, J. J., \& Hamaker, C. (2000). Intellectual ability, learning style, personality, achievement motivation and academic success of psychology students in higher education. Personality and Individual Differences, 29, 1057-1068.

Charlot, O., \& Decreuse, B. (2005). Self-selection in education with matching frictions. Labour Economics, 12(2), 251-267.

Chevalier, A. (2003): Measuring over-education, Economica, 70(279), 509-531.

Clark, A. E. (1996). Job satisfaction in Britain, British Journal of Industrial Relations, 34, 189-217.

Clark, A. E., \& Oswald, A. J. (1996). Satisfaction and comparison income. Journal of Public Economics, 61, 359-381.

Cohn, E. (1992). The impact of surplus schooling on earnings: Comment. Journal of Human Resources, 27(4), 679-682.

Cohn, E., \& Khan, S. P. (1995). The wage effects of overschooling revisited. Labour Economics, 2, $67-76$.

Cranny, C. J., Smith, P. C., \& Stone, E. F. (1992). Job satisfaction: How people feel about their jobs and how it affects their performance. New York: Lexington.

De Grip, A., Van Loo, J., \& Mayhew, K. (2002). The economics of skills obsolescence: theoretical innovations and empirical applications. Research in Labor Economics, 21, 1-273.

De la Fuente, A. \& Ciccone, A. (2003). Human Capital in a Global and Knowledge-based Economy, European Comission, DG. For Employment and Social Affairs, Luxembourg.

Dolton, P. J., \& Makepeace, G. M. (1990). Graduate earnings after six years: Who are the winners? Studies in Higher Education, 15(1), 31-55.

Duncan, G. J., \& Hoffmann, S. D. (1981). The incidence and wage effects of overeducation. Economics of Education Review, 1(1), 75-86.

Fehr, E., \& Falk, A. (2002). Psychological foundations of incentives. European Economic Review, 46, $687-724$.

Goodman, L. A. (1986). Some useful extensions of the usual correspondence analysis approach and the usual log-linear models approach in the analysis of contingency tables. International Statistics Review, 54, 243-309.

Green, W. H. (1997). Econometric analysis (3rd ed.). New Jersey: Prentice-Hall.

Groeneveld, S., \& Hartog, J. (2004). Overeducation, wages and promotions within the firm. Labour Economics, 11(6), 701-714.

Hartog, J. (1988). An ordered response model for allocation and earnings. Kyklos, 41(1), 112-141.

Hartog, J. (1992). Capabilities, allocation and earnings. Boston: Kluwer.

Hartog, J. (2000). Over-education and Earnings: Where are we, where should we go? Economics of Education Review, 19(2), 131-147.

Hartog, J. (2001). On human capital and individual capabilities. Review of Income and Wealth, 47(4), $515-540$.

Hartog, J., \& Oosterbeek, H. (1988). Education, allocation and earnings in the Netherlands: Overschooling? Economics of Education Review, 7(2), 185-194. 
Heijke, H., Meng, C., \& Ramaekers, G. (2002). An investigation into the role of human capital competencies and their pay-off. Research Memorandum, ROA, Maastricht.

Heijke, H., Meng, C., \& Ris, C. (2003). Fitting to the job: The role of generic and vocational competences in adjustment and performance. Labour Economics, 10(2), 215-229.

Hoogveld, A. W. M., Paas, F., \& Jochems, W. M. G. (2005). Training higher education teachers for instructional design of competency-based education: product-oriented versus process-oriented worked examples. Teaching and Teacher Education, 21(3), 287-297 .

Igalens, J., \& Roussel, P. (1999). A study of the relationship between compensation package, work motivation and job satisfaction. Journal of Organizational Behaviour, 20, 1003-1025.

Ishikawa, M., \& Ryan, D. (2002). Schooling, basic skills and economic outcomes. Economics of Education Review, 21, 231-243.

Johnson, G. J., \& Johnson, W. R. (2000). Perceived over-qualification and dimensions of job satisfaction: A longitudinal analysis. Journal of Psychology, 134(5), 537-555.

Jovanovic, B. (1979). Job matching and the theory of turnover. Journal of Political Economy, 87, $1246-1260$.

Jovanovic, B. (1984). Matching, turnover and unemployment. Journal of Political Economy, 92, $108-122$.

Kang, S., \& Bishop, J. (1989). Vocational and academic education in high school: Complements or substitutes? Economics of Education Review, 8(2), 133-148.

Kellermann, P. (2007). Acquired and required competencies of graduates. In U. Teichler (Ed.), Careers of university graduates: Views and experiences in comparative perspectives. Dordrecht: Kluwer (in press).

Kuh, G. D. (1999). How are we doing? tracking the quality of the undergraduate experience, 1960s to the present. The Review of Higher Education, 22(2), 99-120.

Kuh, G. D. (2001). The effects of student-faculty interaction in the 1990s. The Review of Higher Education, 24(3), 309-332.

Kunze, (2005). The evolution of the gender wage gap. Labour Economics, 12(1), 73-97.

Leckey, J. F., \& McGuigan (1997). Right tracks-wrong rails: The development of generic skills in higher education. Research in Higher Education, 38(3), 365-378.

Levy, F., \& Murnane, R. (1992). US earnings levels and earnings inequality: a review of recent trends and proposed explanations. Journal of Economic Literature, 30, 1333-1381.

Lynch, L. (1992). Private sector training and earnings of young workers. American Economic Review, 82, 229-312.

Mariachristina, P., Santarelli, E., \& Vivarelli, M. (2003). The skill bias effect of technological and organisational change: Evidence and policy implications. IZA Discussion Paper Series, Discussion Paper, 934.

Mincer, J. (1974). Schooling, experience and earnings. New York: National Bureau of Economic Research, Columbia University Press.

Neumark, D., \& Wascher, W. (2003). Minimum wages and skill acquisition: Another look at schooling effects. Economics of Education Review, 22, 1-10.

Nordhaug, O. (1993). Human capital in organizations, competence, training and learning. Bergen: Oxford University Press.

Nunnally, J.C., \& Bernstein, I.H. (1994). Psychometric theory (3rd ed). New York: McGraw-Hill.

Oliva, A. (2003). Key competencies in and across social fields: The employers' perspective. In D. S. Ryechen, L. H. Salganik, \& M. E. McLaughlin (Eds.), Selected contributions to the 2nd DeSeCo Symposium. Neuchâtel, Switzerland: Swiss Federal Statistical Office.

Pike, G. R. (1995). The relationship between self-reports of college experiences and achievement test scores. Research in Higher Education, 36(1), 1-22.

Pischke, J. S. (2000). Continuous training in Germany. IZA Discussion Paper, 137. IZA, Bonn.

Raaum, O., \& Torp, H. (2002). Labour market training in norway-effect on earnings. Labour Economics, 9(2), 207-247.

Robie, C., Ryan, A. M., Schmieder, R. A., Parra, L. F., \& Smith, P. C. (1998). The relation between job level and job satisfaction. Group \& Organization Management, 23(4), 470-495.

Robinson, M. A., Sparrow, P. R., Clegg, C., \& Birdi, K. (2005). Design engineering competencies: future requirements and predicted changes in the forthcoming decade. Design Studies, 26(2), $123-153$.

Ross, E., \& Van Willigen, M. (1997). Education and the subjective quality of life. Journal of Health and Social Behavior, 38, 275-297.

Rychen, S., \& Salganik, L. H. (Eds.) (2003). Key competencies for a successful life and a well-functioning society. Göttingen, Germany: Hogrefe and Huger publishers. 
Schomburg, H., \& Teichler, U. Higher education and graduate employment in Europe: Results of graduate survey from twelve countries. Kluwer Pub. (in press).

Sianesi, B., \& Van Reenan, J. (2003). The returns to education: Macroeconomics. The Journal of Economic Surveys, 17(2), 157-200.

Teichler, U., \& Kehm, B. (1995). Towards a new understanding of the relationships between higher education and employment. European Journal of Education, 30(2), 115-132.

Teichler, U., \& Schomburg, H. Careers of higher education graduates, view and experiences in comparative perspectives. Kluwer Pub. (in press).

Thurow, L. C. (1975). Generating inequality. New York: Basic Books.

Topel, R. (1986). Job Mobility, search and earnings growth. Research in Labor Economics, 8, 199-233.

Tyler, J. H., Murnane, R. J., \& Willett, J. B. (2003). Who benefits from a GED? evidence for females from high school and beyond. Economics of Education Review, 22, 237-247.

Van der Heijden, P., De Falguerolles, A., \& De Leeuw, J. (1989). A Combined approach to contingency table análisis using correspondence análisis and log-linear analysis. Applied Statistics, 38, 249-292.

Van Praag, B. (1991). Ordinal and cardinal utility. An integration of the two dimensions of the welfare concept. Journal of Econometrics, 50, 69-89.

Verdugo, R. R., \& Verdugo, N. T. (1989). The impact of surplus of schooling on earnings: Some additional findings. Journal of Human Resources, 24(4), 629-643.

Warr, P. (1992). Age and occupational well-being. Psychology and Aging, 7, 37-45.

Witte, J. C., \& Kalleberg, A. L. (1995). Matching training and jobs: The fit between vocational education and employment in the German labor market. European Sociological Review, 11(3), 293-317.

Yang, M. Y., You, M., Chen, F. C. (2005). Competencies and qualifications for industrial design jobs: implications for design practice, education, and student career guidance. Design Studies, 26(2), $155-189$. 